\title{
PERAN BANK SYARIAH DALAM MENINGKATKAN PEREKONOMIAN NASIONAL MELALUI PEMBIAYAAN MODAL KERJA PADA UMKM
}

\author{
Sujian Suretno1, Bustam² \\ ${ }^{1}$ STAI Al Hidayah Bogor \\ ${ }^{2}$ STAI Al Hidayah Bogor \\ email: sujiansuretno80@gmail.com \\ email: bustam310@gmail.com
}

\begin{abstract}
This study aims to examine the role of Islamic banks as national development agents to improve the community's economy through working capital financing in Micro, Small and Medium Enterprises (MSMEs). The author uses explorative qualitative research methods by examining data and information relating to the role of Islamic banks in improving the community's economy through working capital financing at MSMEs. Sources of data obtained from books, journals, and other relevant reference readings. This paper finds that Islamic bank financing at MSMEs is proven to be able to increase the real sector so that it can boost national finance. Another factor is that the MSME sector has been proven to be able to withstand the economic crisis that occurred in 1997 and 2008. The working capital financing system in Islamic banks is considered to be very suitable for the development of MSMEs which are the driving force of the people's economy. Thus, supporting Islamic banks in the development of MSMEs is expected to be able to run even further by increasing the accessibility of funds and increasing the portion of financing, because at present the share of financing is still smaller compared to consumer financing. $80 \%$ of the total $80 \%$ financing. Keywords: Islamic Banks, MSMEs, Real Sector, Economic Growth.
\end{abstract}

\footnotetext{
ABSTRAK

Penelitian ini bertujuan untuk mengkaji peran bank syariah sebagai agen pembangunan nasional dalam meningkatkan ekonomi masyarakat melalui pembiayaan modal kerja pada Usaha Mikro, Kecil, dan Menengah (UMKM). Penulis menggunakan metode penelitian kualitatif eksploratif dengan mengkaji data dan informasi yang berkaitan dengan peran bank syariah terhadap peningkatan ekonomi masyarakat melalui pembiayaan modal kerja pada UMKM. Sumber data diperoleh dari buku, jurnal, dan bacaan referensi lainnya yang relevan. Tulisan ini menemukan bahwa pembiayaan bank syariah pada UMKM terbukti mampu meningkatkan sektor riil sehingga mampu mendongkrak perekonomian secara nasional. Faktor lainnya adalah karena sektor UMKM telah teruji dapat bertahan menghadapi krisis ekonomi selama dua kali yang terjadi pada tahun 1997 dan tahun 2008. Sistem pembiayaan modal kerja pada bank syariah dirasa sangat cocok bagi pengembangan UMKM yang merupakan urat nadi penggerak ekonomi masyarakat. Dengan demikian, kontribusi bank syariah dalam pengembangan UMKM sangat diharapkan dapat berjalan dengan lebih maksimal lagi dengan meningkatkan aksesibilitas pembiayaan dan meningkatkan porsi pembiayaan, karena pada saat ini porsi pembiayaan produktif kontribusinya masih sangat kecil jika dibandingkan dengan pembiayaan konsumtif. Pembiayaan produktif angkanya masih di bawah $20 \%$ sedangkan pembiayaan konsumtif di atas $80 \%$.

Kata kunci: bank syariah, UMKM, sektor riil, pertumbuhan ekonomi.
} 


\section{A. PENDAHULUAN}

Bank pada hakikatnya adalah lembaga intermediasi keuangan yang mempertemukan pihak yang surplus dana dengan pihak yang defisit dana. ${ }^{1}$ Bank syariah sebagai sebuah lembaga keuangan bertugas menghimpun dana dari masyarakat dalam bentuk simpanan dan menyalurkannya kembali kepada masyarakat dalam bentuk pembiayaan. ${ }^{2}$ Salah satu fungsi utama bank syariah adalah menyalurkan pembiayaan sebagaimana dijelaskan dalam Undangundang Nomor 21 tahun 2008. ${ }^{3}$ Penyaluran dana dalam bentuk pembiayaan tersebut merupakan sumber bisnis utama dan menjadi sumber pendapatan utama bank syariah. Dilihat dari kegiatan usaha yang ada di bank syariah memang lebih variatif ${ }^{4}$ jika dibandingkan dengan kegiatan usaha yang ada di bank konvensional. Bank syariah dalam menyalurkan pembiayaan ke masyarakat dapat disesuaikan dengan

\footnotetext{
1 Hasnil Hasyim. (2017). Perilaku Debitur Dalam Menentukan Pembiayaan Syariah (Studi Kasus Pada Beberapa BPRS Di Wilayah Tangerang dan Bekasi). Ad-Deenar: Jurnal Ekonomi dan Bisnis Islam, 1/02. hlm 1.

2 Ahmad Hasan Ridwan. (2004). BMT \& Bank Islam Intrumen Lembaga Keuangan Syariah. Bandung: Pustaka Bani Quraisy. hlm. 14.

3 Undang-Undang Nomor 21 Tahun 2008, Tentang Perbankan Syariah.

${ }^{4}$ Hani Werdi Apriyanti. (2018). Model Inovasi Produk Perbankan Syariah di Indonesia. Economica: Jurnal Ekonomi Islam, 9/1. hlm. 89.
}

kebutuhan nasabah. ${ }^{5}$ Saat ini banyak sekali masyarakat yang masih terjebak pada kredit berbunga yang diharamkan Allah S.W.T. ${ }^{6}$ sehingga bukan mendapat keuntungan tapi malah mendapatkan kerugian. ${ }^{7}$ Produk-produk yang ada pada pembiayaan bank syariah secara jelas tetap mengacu pada pembiayaan murabahah, mudharabah, musyarakah, dan ijarah dimana akad-akad tersebut digunakan dalam sistem akad-akad dan menghasilkan keuntungan yang adil bagi pihak nasabah dan bagi pihak bank syariah itu sendiri. Akad murabahah misalnya dapat digunakan untuk pembelian aset secara kredit dengan menetapkan harga pokok atau perolehan dan harga jual yang transparan, harga jual ditetapkan berdasarkan kepantasan harga pasar, kemudian mudharabah dan musyarakah, kerjasama bagi hasil dimana keuntungan dibagi berdasarkan nisbah masing-masing pihak yang disepakati di awal akad, jika untung dibagi dan jika rugi ditanggung bersama, dan akad ijarah atau sewa-

5 Nik Amah. (2013). Bank Syariah dan UMKM dalam Menggerakkan Perekonomian Indonesia: Suatu Kajian Literatur. Assets: Jurnal Akuntansi dan Pendidikan, 2/1. hlm. 49.

${ }^{6}$ Abdurrohman Kasdi. (2013). Analisis Bunga Bank dalam Pandangan Fiqih. Iqtishadia, 6/2. hlm. 323.

${ }^{7}$ Sujian Suretno. Jual Beli dalam Perspektif Alquran. Ad-Deenar: Jurnal Ekonomi dan Bisnis Islam, 2/1. hlm. 95. 
menyewa yang mana akad ini lebih dahulu populer di masyarakat. ${ }^{8} \quad$ Akad-akad pembiayaan pada bank syariah didasarkan pada prinsip jual beli, bagi hasil, dan sewamenyewa. Sehingga kegiatan usaha bank syariah betul-betul didapatkan dari usahausaha tersebut dengan menggunakan akadakad yang sesuai dengan prinsip syariah. Upaya-upaya pematuhan terhadap prinsipprinsip syariah telah ditempuh dengan baik oleh bank syariah. ${ }^{9}$

Islam telah memberikan panduan tentang akad-akad syariah untuk mengatur muamalah ${ }^{10}$. Konsep tersebut memberikan peluang yang lebih besar bagi para pelaku UMKM untuk mengembangkan usahausahanya berdasarkan asas kemitraan ${ }^{11}$ sebagaimana yang diselenggarakan oleh bank syariah. Kedudukan UMKM ditengah-tengah masyarakat sangat penting

8 Bhakti, Rizki Tri Anugrah, dkk. (2013). Pemberdayaan UMKM dan Lembaga Keuangan Syariah Melalui Prinsip Bagi Hasil. De Jure: Jurnal Syariah dan Hukum, 5(1). hlm. 15.

9 Sujian Suretno. (2019). Kepatuhan Syariah Pada Produk Musharakah di Bank Syariah Indonesia. Indo-Islamika: Jurnal Kajian Interdisipliner Islam Indonesia, 9(1). hlm. 9.

10 Haryono. (2019). Dinamika dan Solusi Pengembangan Multi Akad (Hybrid Contract) Sebagai Basis Produk Bank Syariah", Ad-Deenar: Jurnal Ekonomi dan Bisnis Islam, 03(01). hlm. 21.

11 Destri Budi Nugraheni. (2010). Asas Kesetaraan dalam Akad Pembiayaan Musyarakah Pada Bank Syariah di Yogyakarta. Mimbar Hukum, 22(1). hlm. 130। dalam mengembangkan perekonomian secara nasional di Indonesia. ${ }^{12}$

Sebagian besar, masyarakat Indonesia sudah terjerat oleh lilitan utang sehingga perekonomian semakin terpuruk. ${ }^{13}$ Dapat dikatakan bahwa UMKM adalah urat nadinya perekonomian nasional, karena dengan hadirnya UMKM maka roda perekonomian dapat berputar dan berjalan dengan baik dan seimbang, selain itu dengan peningkatan UMKM maka akan mempermudah dalam proses penyerapan tenaga kerja, mempermudah arus jual beli di masyarakat karena jual beli merupakan kebutuhan seluruh manusia yang terjadi setiap saat ${ }^{14}$ serta mengurangi presentasi angka pengangguran yang ada saat ini ${ }^{15}$. UMKM terbukti ampuh dan kuat, karena mampu bertahan dan menjadi roda penggerak perekonomian, terutama pasca

12 Sudati Nur Sarfiah. (2019). Hanung Eka Atmaja, Dian Marlina Verawati, "Umkm Sebagai Pilar Membangun Ekonomi Bangsa MSMES The Pillar For Economy, Jurnal Rep: Riset Ekonomi Pembangunan, 4(2). hlm. 139.

13 http://www.deliknews.com/2015/12/29/ ekonomi-terpuruk-kado-jokowi-jk- 2016-untukrakyat/, Ekonomi Terpuruk, Kado Jokowi-JK 2016 untuk Rakyat, diunduh pada hari Jumat tanggal 23 Desember 2016.

14 Sujian Suretno. (2018). Jual Beli dalam Perspektif Alquran. Ad-Deenar: Jurnal Ekonomi dan Bisnis Islam, 2(1). hlm. 101.

15 Muslimin Kara. (2013). Kontribusi Pembiayaan Bank Syariah terhadap Pengembangan Usaha Mikro Kecil dan Menengah (UMKM) di Kota Makassar. Jurnal Asy-Syir'ah: Jurnal Ilmu Syari'ah dan Hukum, 47(1), hlm. 272. 
krisis ekonomi tahun 1998 dan 2008.

UMKM pada saat krisis ekonomi mampu melakukan penyesuaian dan bertahan ketika banyak perusahaan besar mengalami kebangkrutan dan melakukan PHK dalam jumlah yang besar. ${ }^{16}$

\section{B. TINJAUAN PUSTAKA}

Dalam bermuamalah, Islam sangat menjunjung tinggi prinsip keadilan dan kepatuhan syariah. ${ }^{17}$ Prinsip keadilan dan kepatuhan syariah dapat menciptakan rasa adil dan ketentraman pada pihak-pihak yang melakukan kerjasama dalam muamalah bisnis. ${ }^{18}$ Dasar muamalah dalam Islam adalah akad. Setiap muamalah diikat oleh suatu perjanjian yang menjelaskan prinsip dan etika antara sesama manusia. ${ }^{19}$ Kejelasan prinsip dan etika menjadi pegangan yang sangat kuat bagi kedua

16 Y. Sri Susilo. (2010). Strategi Bertahan Industri Makanan Skala Kecil Pasca Kenaikan Harga Pangan dan Energi di Kota Yogyakarta. Ekuitas, 14(2). hlm. 237.

${ }^{17}$ Sujian Suretno. (2019). Kepatuhan Syariah Pada Produk Musharakah di Bank Syariah Indonesia. Indo-Islamika: Jurnal Kajian Interdisipliner Islam Indonesia, 9(1). hlm. 11.

18 Sujian Suretno. (2018). Pelaksanaan Musyarakah di Bank Syariah Mandiri, Kajian Prinsip Keadilan dan Kepatuhan Syariah. Cirebon: Nusa Litera Inspirasi. hlm. 178.

${ }^{19}$ Antony. (2018). Etika dan Bisnis Perspektif Ekonomi Islam. Profit: Kajian Jurnal Ekonomi dan Perbankan, 2(1). hlm. 7. belah pihak yang menjalankan kerjasama bisnis. ${ }^{20}$

Bank syariah dengan sistem keuangannya berusaha untuk mengakomodir kebutuhan bisnis nasabah ${ }^{21}$ dengan berbagai akad yang mendukung dan sesuai dengan prinsip dan model bisnis yang dijalankan. Tetapi bank syariah tetap harus dipahami sebagai lembaga intermediasi keuangan, ${ }^{22}$ bukan lembaga bisnis murni seperti perusahaan, $\mathrm{CV}$, dan lain-lain yang bisa terjun langsung ke sektor riil. Bank syariah dalam bekerjasama dengan nasabah untuk menjalankan kegiatan usahanya tetap melaksanakan fungsinya sebagai lembaga intermediasi yang terikat oleh banyak aturan-aturan dari lembaga-lembaga yang memfasilitasinya seperti BI, OJK, DSNMUI, DPS, Basyarnas, LPS, Jamsyar, dan lain-lain.

Dalam dunia bisnis yang terus berkembang dengan pesat, akad-akad bisnis dalam Islam harus dipahami dan

20 M. Umer Chapra. (2008 dan 2009). Ethics and Economics: An Islamic Perspective, Islamic Economic Studies, 16(1\&2). hlm. 4.

${ }^{21}$ M. Umer Chapra. (2001). Islamic Economic Thougth, and The New Global Economy. Islamic Economic Studies, 9(1). hlm. 13.

22 Ratna Mutia, Khairul Aswadi, Martahadi. (2017). Hakikat Fungsi Intermediasi Perbankan Syariah: Studi Kasus di Kota Banda Aceh. Jurnal Ekonomi dan Kebijakan Publik Indonesia, 4(2). hlm. 122. 
dikuasai oleh kedua belah pihak, baik pihak bank maupun pihak masyarakat (individu dan perusahaan) sebagai pelaku bisnis.

\section{METODE PENELITIAN}

\section{Jenis Penelitian}

Jenis penelitian ini adalah kualitatif ekporatif. ${ }^{23}$ Metode ini berusaha menggali secara luas terkait dengan faktor-faktor tertentu yang mempengaruhi terjadinya sesuai dalam pokok penelitian. Metode penelitian eksploratif juga bertujuan untuk memetakan permasalahan secara mendalam untuk mencari sebab-sebab yang mempengaruhi sesuatu secara lebih spesifik, sehingga akan menguatkan asumsi-asumsi pada inti permasalahan penelitian. Metode ini juga berupaya melakukan pengamatan secara sistematis pada situasi sosial yang tengah terjadi dan terus berkembang (dinamis), sehingga dapat mengungkap objek kajian secara komprehensif dan fenomenologis. ${ }^{24}$ Penelitian eksploratif harus dilakukan dengan jujur, transparan, dan mengikuti

23 Sage Research Method. (2019). What Is Exploration?: In: Exploratory Research in the Social Sciences, SAGE Publications. hlm. 2.

${ }^{24}$ W. Gulo. (2000). Metodologi Penelitian. Jakarta: Gramedia Widiasarana Indonesia. hlm. 18. serangkaian pedoman untuk memastikan keandalannya. $^{25}$

\section{Pendekatan Penelitian}

Penulis menggunakan pendekatan ${ }^{26}$ induktif $^{27}$ untuk mengambil kesimpulan secara global berdasarkan data-data dan fakta-fakta yang terjadi di lapangan. Kesimpulan yang ditarik dimulai dengan menyatukan pertanyaan-pertanyaan yang bersifat umum dan mendominasi fakta riil di lapangan. Pendekatan induktif digunakan untuk beberapa faktor, di antaranya adalah untuk menguraikan latar secara penuh, untuk menemukan pengaruh dan mempertajam hubungan, untuk menentukan hitungan-hitungan nilai secara eksplisit yang didapatkan dari hasil analisis data. Pendekatan induktif sangat bertumpu pada data dan fakta di lapangan yang dihubungkan dengan teori yang relevan

25 Bernd Reiter. (2017). Theory and Methodology of Exploratory Social Science Research, University of South Florida, Scholar Commons. hlm. 137.

26 Pendekatan adalah upaya-upaya yang ditempuh untuk memperoleh kebenaran baik dengan pendekatan ilmiah maupun non ilmiah. Lihat Sandu Siyoto dan Ali Sodik. (2015). Dasar Metodologi Penelitian. Yogyakarta: Literasi Media Publishing. hlm. 1.

27 Pendekatan induktif adalah upaya untuk membangun suatu teori yang didasarkan pada data dan fakta yang terjadi di lapangan. Untuk itu datadata yang disajikan harus bersumber dari data yang sahih dan dapat dikonfirmasi kebenarannya. Mohammad Mulyadi. (2011). Penelitian Kuantitatif dan Kualitatif Serta Pemikiran Dasar Menggabungkannya. Jurnal Studi Komunikasi dan Media, 15(1). hlm. 128. 
sehingga menghasilkan kesimpulan yang tepat.

\section{Teknik Pengumpulan Data}

Penulis menggunakan teknik pengumpulan data secara terbatas dengan dua metode berikut ini:

\section{a. Observasi}

Penulis melakukan pengamatan secara cermat terkait dengan datadata dan fakta-fakta yang terjadi di lapangan. ${ }^{28}$ Data-data yang diamati adalah data yang bersumber dari beberapa referensi penting, baik jurnal nasional, jurnal internasional, informasi resmi dari Otoritas Jasa Keuangan (OJK), Bank Indonesia (BI), dan bahan-bahan informasi relevan lainnya.

\section{b. Studi Dokumentasi}

Penulis juga melakukan studi dokumentasi $^{29} \quad$ untuk mengumpulkan dokumen-dokumen terkait data-data penelitian yang

28 Alan Bryman. (2008). Social Research Method, 4th Edition. Oxford: University Press. hlm. 92.

29 Data-data dokumen merupakan catatan peristiwa yang sudah berlalu. Dokumen berbentuk tulisan, gambar, karya monumental dari seseorang, dan lain-lain. Penulis mengumpulkan dokumendokumen dalam bentuk tulisan yang sudah dipublish secara resmi oleh beberapa otoritas tertentu terkait dengan bank syariah, OJK, UMKM, dan lain-lain. Ida Farida. (2010). Studi Dokumen dalam Penelititan Kualitatif. Jurnal Sains dan Inovasi, 6(1). hlm. 55. dapat diunduh secara langsung dari situs-situs yang dimaksudkan.

\section{Fokus Penelitian}

Topik penelitian difokuskan pada peran bank syariah sebagai agen pembangunan ekonomi nasional untuk menggerakkan sektor riil $^{30}$ sehingga perekonomian secara nasional meningkat. Penulis akan melakukan kajian secara mendalam untuk membangun kerangka berpikir secara logis terkait dengan pengaruh pembiayaan modal kerja pada UMKM sehingga dapat mendorong perekonomian secara nasional sesuai dengan amanah undang-undang bank syariah nomor 21 tahun 2008 .

\section{Pengolahan Data}

Tahap-tahap pengolahan data ${ }^{31}$ yang dilakukan adalah sebagai berikut:

\section{a. Reduksi Data}

${ }^{30}$ Sektor riil adalah sektor yang bersentuhan langsung dengan kegiatan ekonomi masyarakat, sektor ini sangat mempengaruhi pertumbuhan ekonomi. dalam sebuah teori disebutkan bahwa sektor riil adalah mesin yang menggerakkan roda perekonomian. Karena sektor riil adalah sektor yang nyata, sektor yang menghasilkan barang dan jasa di masyarakat. Untuk itu sektor riil perlu terus ditingkatkan untuk mempercepat pertumbuhan ekonomi secara nasional. Oleh karena itu bank syariah sebagai lembaga keuangan diberikan amanah oleh undang-undang untuk fokus membiayai sektor riil. Ina Sholati Cahyaningrum. (2017). Pengaruh Sektor Riil dan Keuangan Syariah Terhadap Pertumbuhan Ekonomi di Indonesia Tahun 2007-2014. An-Nisbah, 04(01). hlm. 111.

31 Ahmad Rijali. (2018). Analisis Data Kualitatif. Jurnal Al-Hadharah, 17(33). hlm. 92. 
Penulis mengumpulkan data-data secara terperinci. Data-data tersebut kemudian dikategorisasikan berdasarkan data-data prioritas yang dibutuhkan kemudian direduksi. ${ }^{32}$ Data-data yang dianggap tidak penting diabaikan. Data dipilih berdasarkan satuan konsep, tema, dan kategori tertentu agar dapat menggambarkan lebih tajam permasalahan yang dihasilkan dari pengamatan.

\section{b. Penyajian Data}

Data yang

diperoleh

dikategorisasikan menurut pokok permasalahan dan dibuat dalam bentuk matriks sehingga memudahkan peneliti untuk melihat pola-pola hubungan antara satu data dengan data lainnya. ${ }^{33}$

\section{c. Analisis Data}

Data yang telah disajikan akan diorganisasikan kemudian mencari dan menemukan pola. Kemudian menginventarisir temuan-temuan dan menghubungkannya dengan teori yang sesuai dengan bidang

32 Sandu Siyoto, Ali Sodik. (2015). Dasar Metodologi Penelitian. Yogyakarta: Literasi Media Publishing. hlm. 32

33 Suyitno. (2018). Metode Penelitian Kualitatif, Konsep, Prinsip, dan Operasionalnya. Tulung Agung: Akademia Pustaka. hlm. 138. kajian. Setelah itu data diinterpretasikan dan dimaknai untuk ditarik pada suatu kesimpulan. Inti dari analisis data adalah penarikan kesimpulan dan verifikasi. $^{34}$

\section{d. Menyimpulkan}

dan Memverifikasi Data

Langkah selanjutnya adalah menyimpulkan dan melakukan verifikasi atas data-data yang sudah diproses atau ditransfer ke dalam bentuk-bentuk tertentu yang sesuai dengan pola pemecahan permasalahan yang dilakukan. Verifikasi dilakukan untuk melakukan suatu pembenaran dari data yang diamati. ${ }^{35}$

\section{e. Menarasikan Hasil Analisis}

Pembahasan dalam penelitian kualitatif menyajikan informasi dalam bentuk teks tertulis yang mendeskripsikan kesimpulan hasil penelitian secara global berdasarkan teori yang diujikan dalam pertanyaan penelitian. Hasil analisis menggambarkan temuan-temuan penelitian dan hasil-hasil jawaban yang dari pertanyaan-pertanyaan penelitian yang melahirkan kritik

\footnotetext{
${ }^{34}$ Suyitno. (2018). hlm. 156.

${ }^{35}$ Sandu Siyoto, Ali Sodik. (2015). hlm. 61.
} 
dan rekomendasi hasil penelitian sebagaimana diungkapkan oleh Miles dan Huberman. ${ }^{36}$

\section{PEMBAHASAN}

Prinsip syariah pada Bank Syariah merupakan bagian dari ajaran Islam yang berkaitan dengan ekonomi. Salah satu prinsip dalam ekonomi Islam adalah larangan riba dalam berbagai bentuknya. ${ }^{37}$ Selama Allah Ta'ala mengharamkan riba maka tidak ada alasan lagi untuk membantah atau menolaknya. ${ }^{38}$ Dengan prinsip bagi hasil, Bank Syariah dapat menciptakan iklim investasi yang sehat dan adil karena semua pihak dapat saling berbagi baik keuntungan maupun potensi risiko yang timbul sehingga akan menciptakan posisi yang berimbang antara bank dan nasabahnya. Bagi hasil merupakan instrumen halal yang digunakan untuk kerjasama baik mudarabah atau musyarakah. ${ }^{39}$ Dalam jangka panjang, hal ini akan mendorong

37 Sujian Suretno. (2018). Pelaksanaan Musyarakah di Bank Syariah Mandiri, Kajian Prinsip Keadilan dan Kepatuhan Syariah. Cirebon: Nusa Litera Inspirasi. hlm. 5.

38 Abu Bakar Jabir Al-Jazairi. (2015). Tafsir Alquran Al-Karim, Al-Aisar. Yogyakarta: Darus Sunnah Press. hlm. 470.

39 Sujian Suretno. (2018). Jual Beli dalam Perspektif Alquran. Ad-Deenar: Jurnal Ekonomi dan Bisnis Islam, 2(1). hlm. 169. pemerataan ekonomi nasional karena hasil keuntungan tidak hanya dinikmati oleh pemilik modal saja, tetapi juga oleh pengelola modal. ${ }^{40}$

Peran Bank Syariah dalam pembiayaan UMKM adalah dalam bentuk pembiayaan. Bank Syariah memberikan pembiayaan dalam bentuk modal kerja kepada pelaku UMKM, sehingga dengan modal kerja tersebut sektor-sektor rill dimasyarakat dapat meningkat sehingga produk-produk yang dibutuhkan oleh masyarakat dapat terpenuhi. Di negara maju, UMKM sangat penting, tidak hanya kelompok usaha tersebut yang menyerap paling banyak tenaga kerja dibandingkan usaha besar (UB), seperti halnya di negara sedang berkembang, tetapi juga kontribusinya terhadap pembentukan atau pertumbuhan produk domestik bruto (PDB) paling besar dibandingkan kontribusi dari usaha besar. ${ }^{41}$ UMKM terbukti sangat berpengaruh positif terhadap pendapatan nasional. ${ }^{42}$

${ }^{40}$ Undang-undang Bank Syariah No.21 Tahun 2008. Hlm.37.

${ }^{41}$ Lu'lu'ul Husniatuz Zuhroh. (2018). Analisis Pengaruh Aset Daerah dan Belanja Modal Terhadap Produk Domestik Regional Bruto di Koridor Utara Selatan Provinsi Jawa Timur. Jurnal Ilmu Ekonomi, 2(2). hlm. 242.

${ }^{42}$ Lies Maria Hamzah, Devi Agustien. (2019). Pengaruh Perkembangan Usaha Mikro, Kecil, dan Menengah Terhadap Pendapatan Nasional Pada Sektor UMKM di Indonesia. Jurnal Ekonomi Pembangunan, 8(2). hlm. 227. 
Menurut Awalil Rizky yang dikutip oleh Euis Amalia bahwa usaha mikro adalah usaha informal yang memiliki asset, modal dan omzet yang relative kecil. Sedangkan usaha kecil menunjuk kepada kelompok usaha yang lebih baik dari itu, tetapi masih memiliki sebagian ciri tersebut ${ }^{43}$.

Bagi industri bank yang dalam hal ini adalah bank syariah, proses penyaluran pembiayaan yang mereka lakukan terhadap sektor UMKM lebih menguntungkan dibandingkan sektor non UMKM, sebab sektor UMKM memiliki ketahanan bisnis yang lebih kuat. Di samping itu faktor pendukung lainnya yang juga akan menguntungkan bank syariah yaitu terkait dengan pembiayaan UMKM yang saat sekarang ini mendapat alokasi bantuan yang besar dari pemerintah terkait dengan pengembangan UMKM tersebut, karena alokasi pembiayaan yang cukup besar tersebut lahir dan dipicu oleh keinginan pemerintah agar industri bank nasional memiliki kontribusi lebih besar dalam mendorong pengembangan sektor UMKM. Perkembangan pembiayaan bank syariah di Indonesia untuk sektor UMKM pada tahun

43 Euis Amalia. (2009). Keadilan Distributif dalam Ekonomi Islam. Jakarta: Rajawali Press. hlm.41.
2019 cenderung meningkat hal ini didasarkan pada tabel berikut ini:

Tabel 1.1

Pembiayaan Bank Umum Syariah Agustus 2019

\begin{tabular}{|c|c|c|c|}
\hline \multirow{2}{*}{ No } & $\begin{array}{c}\text { Penggunaan dan } \\
\text { Kategori Usaha }\end{array}$ & Alokasi & $\begin{array}{c}\text { Agustus } \\
\mathbf{2 0 1 9}\end{array}$ \\
\hline \multirow{2}{*}{1} & Modal Kerja & UMKM & 39.212 \\
\cline { 3 - 4 } & & Bukan UMKM & 65.587 \\
\hline \multirow{2}{*}{2} & Investasi & UMKM & 23.049 \\
\cline { 3 - 4 } & & Bukan UMKM & 59.004 \\
\hline 3 & Konsumsi & Bukan UMKM & 149.573 \\
\hline
\end{tabular}

Dari data di atas dapat disimpulkan bahwa pembiayaan bank syariah untuk modal kerja UMKM lebih tinggi yaitu 39.212, apabila dibandingkan dengan jenis pembiayaan investasi untuk sektor UMKM yang hanya memiliki nilai 23.049. Hal ini menunjukkan bahwa penyerapan pembiayaan UMKM cukup signifikan dan harus terus ditingkatkan.

Perkembangan pembiayaan bank syariah untuk sektor UMKM pada 2019 cenderung meningkat yang dikutip dari situs resmi $\mathrm{OJK}^{45}$. Berikut ini adalah pembiayaan bank umum syariah dan unit usaha syariah berdasarkan jenis

${ }^{44}$ https://www.ojk.go.id/id/kanal/syariah/datadan-statistik/statistik-bank-syariah/Pages/StatistikBank-Syariah---Agustus-2019.aspx ， diakses tanggal 1 Desember 2019.

45 https://www.ojk.go.id/id/kanal/syariah/datadan-statistik/statistik-bank-syariah/Pages/StatistikBank-Syariah---Agustus-2019.aspx , diakses tanggal 1 Desember 2019. 
penggunaan dan kategori usaha (miliar $\mathrm{Rp})$.

Kontribusi yang diberikan oleh UMKM sangatlah besar terhadap perekonomian Indonesia dari dulu hingga saat ini. Ada beberapa alasan mengapa UMKM dapat bertahan di tengah krisis moneter 1997 dan krisis tahun 2008 lalu yang merenggut banyak perekonomian di berbagai Negara Eropa bahkan Asia. Pertama, sebagian besar UMKM memproduksi barang konsumsi dan jasajasa dengan elastitas permintaan terhadap pendapatan yang rendah, maka tingkat pendapatan rata-rata masyarakat tidak banyak berpengaruh terhadap permintaan barang yang dihasilkan. ${ }^{46}$

Sebaliknya, kenaikan tingkat pendapatan juga tidak berpengaruh pada permintaan. Kedua, sebagian besar UMKM tidak mendapat modal dari bank. Implikasinya keterpurukan sektor bank dan naiknya suku bunga, tidak banyak mempengaruhi sektor ini. Di Indonesia, UMKM mempergunakan modal sendiri

46 Berdasarkan penelitian Singgih bahwa UMKM pada masa krisis tahun 97 terbukti dapat bertahan dengan baik. UMKM cukup mapan dan dinamis dalam menghadapi masa krisis. Mohamad Nur Singgih. (2007). Strategi Penguatan Usaha Mikro Kecil Menengah (Umkm) Sebagai Refleksi Pembelajaran Krisis Ekonomi Indonesia. Jurnal Ekonomi Modernisasi, 3(3). hlm. 220. dari tabungan dan aksesnya terhadap pembiayaan bank sangat rendah.

Peran usaha mikro kecil dan menengah ini dalam menggerakkan ekonomi nasional adalah dapat menyerap tenaga kerja yang besar, dapat meningkatkan pendapatan domesik bruto (PDB), serta mampu bertahan dalam menghadapi krisis ekonomi. Dalam sektor UMKM, persoalan utama yang sering terjadi adalah masalah permodalan. Tingkat suku bunga kredit yang tinggi dan diperlukannya jaminan aset kebendaan adalah salah satu faktor penyebab UMKM mengalami kesulitan dalam memperoleh modal usaha. Dengan adanya produk pembiayaan bagi hasil yang ditawarkan oleh bank syariah dapat membantu pertumbuhan sektor UMKM untuk bekerja secara optimal. 
Dengan demikian, kontribusi bank syariah dalam pengembangan UMKM sangat diharapkan dapat berjalan dengan lebih maksimal. Salah satu contohnya adalah dengan meningkatkan aksesibilitas pembiayaannya yaitu memberikan persyaratan yang lebih mudah serta dilakukan adanya pelatihan dan pendampingan usaha. Bank syariah diharapkan dapat terus berkembang dalam memberdayakan UMKM. UMKM yang memiliki potensi besar dalam meningkatkan pendapatan domestik bruto masih terkendala modal dan keterbatasan $\operatorname{akses}^{47}$.

Bank syariah adalah bank yang beroperasi sesuai dengan prinsip-prinsip syariah Islam, maksudnya adalah bank yang dalam operasinya mengikuti ketentuan-ketentuan syariah Islam, khususnya yang menyangkut tata cara bermuamalah secara ajaran Islam. Dalam kehidupan bermuamalah, seorang muslim tidak dapat dilepaskan dengan akad muamalah yang mereka lakukan dalam kehidupan sehari-hari. Islam telah memberikan panduan tentang akad-akad

47 L Anggraeni, Herdiana P, Salahuddin EA, Ranti W. (2013). Akses UMKM Terhadap Pembiayaan Mikro Syariah dan Dampaknya Terhadap Perkembangan Usaha: Kasus BMT Tadbiirul Ummah, Kabupaten Bogor. Jurnal AlMuzara'ah, I(1). hlm. 57. syariah untuk mengatur muamalah. Perkembangan bank syariah memiliki peranan yang signifikan pada pertumbuhan bank syariah di Indonesia. Dengan semaraknya perkembangan bank syariah maka diharapkan secara optimal dapat membantu perkembangan UMKM. Sektor UMKM memberikan kontribusi yang sangat penting bagi perekonomian Indonesia pada masa krisis dimana UMKM memiliki daya tahan menghadapi krisis ekonomi yang terjadi.

Di Indonesia saat ini UMKM dianggap sebagai cara yang efektif dalam pengentasan kemiskinan. UMKM telah diatur secara undang-undang nomor 20 Tahun 2008 tentang usaha mikro, kecil dan menengah. UMKM merupakan kelompok pelaku ekonomi terbesar dalam perekonomian Indonesia dan menjadi sektor terbesar kontribusinya terhadap pembangunan nasional. UMKM sendiri menghadapi berbagai masalah yang belum terselesaikan yang berhubungan dengan iklim usaha.

Persoalan terbesar UMKM adalah kesulitan mengakses permodalan, pengelolaan usaha yang masih tradisional, kualitas SDM yang belum memadai, serta skala dan teknik produksi yang masih 
rendah $^{48}$. Menurut undang-undang nomor 7 tahun 1992 tentang bank sebagaimana telah diubah dengan undang-undang Nomor 10 Tahun 1998 pengertian bank adalah badan usaha yang menghimpun dana dari masyarakat dalam bentuk simpanan dan menyalurkan kepada dalam bentuk kredit dan atau bentuk-bentuk lainnya dalam rangka meningkatkan taraf hidup rakyat banyak $^{49}$. Berdasarkan definisi tersebut, bahwa aktivitas utama bank adalah menghimpun dana dari masyarakat dalam bentuk simpanan yang menjadi sumber dana bank, kemudian bank menyalurkan dalam bentuk kredit, dengan tujuan untuk meningkatkan taraf hidup masyarakat. Namun, Pemahaman riba dan bahayanya harus menjadi prinsip hidup bagi setiap muslim $^{50}$. Hal inilah yang menjadikan peran bank syariah sangat dibutuhkan dalam pembiayaan UMKM karena menggunakan prinsip-prinsip syariah dalam setiap akad-akad pembiayaannya.

48 Sri Maulida, Ahmad Yunani. (2015). Peluang dan Tantangan Pengembangan Usaha Mikro Kecil Menengah (UMKM) dari Berbagai Aspek Ekonomi. Jurnal Ilmiah Manajemen dan Bisnis, 2(1). hlm. 12.

49 Undang-undang Bank Syariah No.7 Tahun 1992.

50 Sujian Suretno. (2018). Pelaksanaan Musyarakah di Bank Syariah Mandiri, Kajian Prinsip Keadilan dan Kepatuhan Syariah. Cirebon: Nusa Litera Inspirasi. hlm. 9.
Seperti dijelaskan sebelumnya bahwa hadirnya UMKM juga menciptakan peluang kerja yang cukup besar bagi tenaga kerja dalam negeri, sehingga sangat membantu dalam upaya mengurangi pengangguran. Ada beberapa perintah ajaran Islam agar kita gemar melakukan bisnis di sektor UMKM, ${ }^{51}$ yaitu:

a. Berbisnis bagian dari kehidupan sebagaimana firman Allah dalam surat Al-Jumu'ah ayat 10 yang artinya "Apabila telah ditunaikan shalat, Maka bertebaranlah kamu di muka bumi; dan carilah karunia Allah dan ingatlah Allah banyak-banyak supaya kamu beruntung". 52

b. Berbisnis mencari ridha Allah (keberkahan), bukan untung. Kegiatan bisnis bagi umat Islam ditujukan tidaklah untuk mencari untung yang besar semata sebab bila pelaku bisnis hanya mengutamakan untung yang besar, maka yang bersangkutan akan terjebak pada mengejar laba baik halal maupun haram atau tidak sah. Berbisnis dalam Islam tidaklah

${ }^{51}$ Irfadilla. (2011). Peran Bank Syariah dalam Mendorong Usaha Kecil dan Menengah Menurut Tinjauan Ekonomi Islam. Universitas Islam Negeri Sultan Syarif Karim. hlm. 39.

52 Alquran: Surah Al-Jumu'ah: 10, Alquran dan Terjemahnya, Departemen Agama Republik Indonesia. 
mengutamakan untung besar, tetapi berusaha untuk menyenangkan pelanggan dalam membeli produk kita. Oleh karena itu seorang muslim dalam berbisnis harus ikhlas, dan memberi kesan baik kepada pembeli.

c. Berbisnis sama dengan manifestasi kerja keras. Suatu hasil usaha yang diperoleh dengan cara bekerja keras, membanting tulang, mandi keringat merupakan rezeki yang halal dalam ajaran Islam. Suatu kegiatan bisnis merupakan suatu kerja keras, karena ia didahului oleh kepercayaan pada diri sendiri, membuat prestasi dengan sepenuh hati, keberanian menerima risiko, serta memasang niat untuk hanya mencari ridha Allah semata. Dalam kerja keras ini mengandung unsur kepuasan bathin, yang tidak dinikmati oleh profesi lain. Agama Islam tidak hanya menekankan kerja keras untuk dunia semata, atau untuk akhirat saja, tetapi untuk kedua-duanya. Artinya dalam mencari kehidupan dunia jangan sampai melupakan bekal untuk akhirat.

Perhatian dalam bentuk upaya pengembangan UMKM harus dilaksanakan secara terintegrasi dengan pembangunan ekonomi nasional dan berkesinambungan.
Berkaca dari peristiwa krisis yang ekonomi yang terjadi pada tahun 1998 membuktikan betapa tangguhnya bank syariah dan UMKM yang ada di Indonesia, maka hendaknya bank syariah dan UMKM senantiasa bersama membangun perekonomian masyarakat. Saat ini dunia usaha khususnya di Indonesia memiliki permasalahan mengenai pendanaan atau permodalan. Para pelaku usaha pastinya memerlukan modal untuk menjalankan usahanya tersebut, dan di sini lah bank syariah berperan dalam menyediakan modal dengan menggunakan produk bank syariah yang cocok dengan UMKM tersebut. Maka dari itu kehadiran bank syariah diharapkan bisa sangat membantu perkembangan usaha masyarakat.

Pembiayaan dengan akad mudharabah dan musyarakah pada dasarnya merupakan pembiayaan yang efektif, pada pembiayaan tersebut digunakan prinsip bagi hasil keuntungan (Profit Sharing). Selain menggunakan prinsip bagi hasil keuntungan, hal lain yang membuat ideal adalah adanya pembagian kerugian (Loss Sharing). Kerugian pada pembiayaan dengan akad mudharabah akan ditanggung sepenuhnya oleh bank, kecuali bila nasabah melakukan kelalaian atau adanya unsur kesengajaan yang menyebabkan 
terjadinya suatu kerugian. Kerugian pada pembiayaan dengan akad musyarakah akan dihitung sesuai dengan porsi modal masing-masing pihak, yaitu pihak bank dan nasabah.

Pada dasarnya dengan prinsip bagi kerugian (loss sharing) ini, maka kedua pihak yaitu pihak nasabah dan pihak bank akan berusaha untuk menghindari terjadinya kerugian tersebut. Dan secara otomatis masing-masing pihak yang berakad akan sangat berhati-hati dalam menjalankan kegiatan bisnis.

Pemerintah telah banyak melakukan berbagai program untuk mengentaskan kemiskinan. ${ }^{53}$ Namun pada kenyataannya program-program tersebut belum tepat sasaran. Maka perlu adanya rancang bangun yang baru agar dapat dipastikan bahwa program tersebut terarah dan tepat sasaran. Sistem ekonomi Islam termasuk

${ }^{53}$ Saat ini pemerintah memiliki tujuh program untuk mengentaskan kemiskinan, di antaranya adalah program Indonesia Pintar (PIP), Program Indonesia Sehat (PIS), Program Keluarga Harapan $(\mathrm{PKH})$, Beras Sejahtera (Rastra) atau yang disebut bantuan sosial pangan, kemudian Bantuan Pangan Non Tunai (BPNT), Dana Desa, dan Reforma Agraria, dan Perhutanan Sosial. Dengan programprogram tersebut pemerintah optimis dapat mengurangi angka kemiskinan secara berkelanjutan. https://katadata.co.id/berita/2018/10/25/ stafsusekonomi-jokowi-paparkan- program- kemiskinantujuh-era-presiden-ri, Rizka Alika. (2020). Stafsus Jokowi Paparkan Program Penurunan Kemiskinan 7 Era Presiden RI, Diakses Pada Tanggal 29 Maret 2020. lembaga keuagan syariah yang ada di dalamnya berhak dan wajib ikut serta mengelola sumber daya yang ada di negara ini. Salah satu di antaranya adalah keterlibatan lembaga keuangan syariah dalam mendorong pemberdayaan dan pertumbuhan UMKM.

Islam sangat memperhatikan masalah pembangunan ekonomi yang didasari oleh nilai-nilai ketauhidan ${ }^{54}$, namun tetap menempatkan perhatian pada pembangunan yang lebih besar, yaitu pembangunan umat manusia. Fungsi utama Islam adalah membimbing manusia pada jalur yang benar dan arah yang tepat. Dalam pembangunan ekonomi, Islam mengajarkan bahwa pemeliharaan terhadap orang yang lemah merupakan kewajiban sebuah negara atau pemerintah. Oleh karena itu, pemerintah harus menumbuhkembangkan segala potensi yang berkaitan dengan usaha pembangunan ekonomi manusia, termasuk pengembangan UMKM.

Dalam mengoptimalisasi pembiayaan produktif untuk mengembangkan UMKM harus diterapkan beberapa prinsip dalam pengelolaan bank syariah. Prinsip-prinsip operasional bank tersebut terdiri dari

54 Hendy Herijanto. (2016). Prinsip, Ketentuan, dan Karakteristik Pembiayaan (Bank) Syariah. Jurnal Islaminomic, 5(2). hlm. 1. 
prinsip kepercayaan (fiduciary principle), prinsip kehati-hatian (prudential principle), prinsip kerahasiaan (confidential principle), dan prinsip mengenal nasabah (know your costumer principle $)^{55}$. Keempat prinsip ini saling berkaitan satu dengan yang lainnya.

Berkaitan dengan optimalisasi pembiayaan produktif ini, maka penerapan prinsip-prinsip pengelolaan bank menjadi suatu keniscayaan bahwa hubungan bank dan nasabah didasarkan pada prinsip kepercayaan, sehingga perlu adanya hubungan saling percaya antara nasabah dengan bank yang didasari keamanahan. Dalam rangka mendapatkan rasa saling percaya maka bank hendaknya mengenal dengan baik karakter dan segala sesuatu yang berkaitan dengan nasabah. Adapun caranya adalah melalui studi kelayakan (feasibility study), misalnya dengan menggunakan prinsip $5 \mathrm{C}^{56}$ ("the five $\mathrm{C}$ 's principles"), yakni menganalisis nasabah yang dalam hal ini adalah UKM pada aspek watak (Character), modal (Capital),

55 https://www.kompasiana.com/rizkykarokaro 156307b13c823bd5811780040/4- empat-prinsipdalam-mengelola-perbankan, 4 (empat) Prinsip dalam Mengelola Perbankan, diunduh pada tanggal 30 Maret 2020.

56 Nanik Eprianti. (2019). Penerapan Prinsip 5c Terhadap Tingkat Non Performing Financing (NPF). Amwaluna: Jurnal Ekonomi dan Keuangan Syariah, 3(2). hlm. 6. kemampuan dalam melunasi kewajiban (Capacity), kondisi ekonomi (Condition of Economic), dan jaminan (Collateral).

Dalam sektor usaha mikro kecil dan menangah (UMKM), persoalan utama yang sering terjadi adalah masalah permodalan. Tingkat suku bunga kredit yang tinggi dan diperlukannya jaminan kebendaan adalah salah satu faktor penyebab UMKM mengalami kesulitan dalam memperoleh modal usaha. Dengan adanya produk pembiayaan bagi hasil yang ditawarkan oleh bank syariah dapat membantu pertumbuhan sektor UMKM untuk bekerja secara optimal. Sektor UMKM memberikan kontribusi yang sangat penting bagi perekonomian Indonesia pada masa krisis dimana UMKM memiliki daya tahan menghadapi krisis ekonomi yang terjadi karena UMKM tidak banyak memiliki ketergantungan pada faktor eksternal seperti hutang dalam valuta asing, dan bahan baku impor dalam melakukan kegiatan operasionalnya (Malik, 2008).

\section{E. KESIMPULAN}

Pembiayaan UMKM oleh bank syariah kepada pelaku UMKM sangatlah berperan penting. Dengan adanya pembiayaan tersebut, maka bank syariah dapat 
mengembangkan perekonomian masyarakat dan juga dapat mengurangi kemiskinan serta menyerap banyak tenaga kerja sehingga secara otomatis mengurangi pengangguran.

Dengan sistem bagi hasil dengan akad Musyarakah maupun Mudharabah yang berbasis kemitraan sehingga dapat mendatangkan ke-maslahatan antara pihak bank syariah dan kepada para pelaku UMKM tersebut. Dengan hadirnya bank syariah dalam pembiayaan UMKM yang diberikan diharapkan akan memberikan hal yang positif dalam pertumbuhan ekonomi masyarakat, para pelaku usaha bisa mengembangkan usaha mereka dan mampu membiayai hidupnya secara konsisten, dan tentunya akan menciptakan kesejahteraan.

Dalam penelitian ini penulis berharap agar bank syariah terus dapat meningkatkan porsi pembiayaan produktif dengan mekanisme bagi hasil untuk mendorong tumbuhnya UMKM di Indonesia. Saat ini pembiayaan bank syariah masih didominasi oleh pembiayaan konsumtif.

Walaupun pembiayaan yang bersifat konsumtif juga dapat digunakan untuk pembiayaan modal kerja, namun jumlahnya masih sangat sedikit. Porsi pembiayaan konsumtif masih di atas 80 persen sementara pembiayaan produktif masih di bawah 20 persen. Besarnya pembiayaan yang bersifat konsumtif lebih mengarah pada transaksi utang-piutang yang dapat melemahkan daya beli masyarakat sebab beban pembayaran utang akan mengganggu kinerja keuangan baik individu maupun perusahaan. Besarnya beban utang akan mengganggu tingkat likuiditas.

Sedangkan jika pembiayaan produktif lebih digencarkan lagi maka hal tersebut dapat mendorong meningkatnya perekonomian masyarakat, sehingga masyarakat akan sejahtera dan sekaligus dapat menguatkan daya beli yang menciptakan sirkulasi ekonomi secara nasional semakin sehat. Penulis berharap bank syariah jangan hanya menjadi transaksi alternatif dalam pembiayaan tetapi juga menjadi solusi bagi sektor UMKM.

\section{DAFTAR PUSTAKA}

Sumber dari Jurnal/Penelititan

Ahmad Rijali. (2018). Analisis Data Kualitatif. Jurnal Al-Hadharah, 17(33).

Bhakti, Rizki Tri Anugrah, dkk. (2013). Pemberdayaan UMKM dan Lembaga Keuangan Syariah Melalui Prinsip 
Bagi Hasil. De Jure: Jurnal Syariah dan Hukum, 5(1).

Destri Budi Nugraheni. (2010). Asas Kesetaraan dalam Akad Pembiayaan Musyarakah Pada Bank Syariah di Yogyakarta. Mimbar Hukum, 22(1).

Hani Werdi Apriyanti. (2018). Model Inovasi Produk Perbankan Syariah di Indonesia. Economica: Jurnal Ekonomi Islam, 9(1).

Haryono. (2019). Dinamika dan Solusi Pengembangan Multi Akad (Hybrid Contract) Sebagai Basis Produk Bank Syariah. Ad-Deenar: Jurnal Bank Syariah, 03(01).

Ida Farida. (2010). Studi Dokumen dalam Penelititan Kualitatif. Jurnal Sains dan Inovasi, 6(1).

Lies Maria Hamzah, Devi Agustien. 92019). Pengaruh Perkembangan Usaha Mikro, Kecil, dan Menengah Terhadap Pendapatan Nasional Pada Sektor UMKM di Indonesia. Jurnal Ekonomi Pembangunan, 8(2).

Lu'lu'ul Husniatuz Zuhroh. (2018). Analisis Pengaruh Aset Daerah dan Belanja Modal Terhadap Produk Domestik Regional Bruto di Koridor Utara Selatan Provinsi Jawa Timur. Jurnal Ilmu Ekonomi, 2(2).

Muslimin Kara. (2013). Kontribusi Pembiayaan Bank Syariah terhadap Pengembangan Usaha Mikro Kecil dan Menengah (UMKM) di Kota Makassar. Jurnal Asy-Syir'ah: Jurnal Ilmu Syari'ah dan Hukum, 47(1).

Nik Amah. (2013). Bank Syariah dan UMKM dalam Menggerakkan Perekonomian Indonesia: Suatu Kajian Literatur. Assets: Jurnal Akuntansi dan Pendidikan, 2(1).
Ramdhansyah. (2013). Pengembangan Model Pendanaan Umkm Berdasarkan Persepsi UMKM. Jurnal Keuangan dan Bisnis, 5(1).

Sudati Nur Sarfiah, Hanung Eka Atmaja, Dian Marlina Verawati. (2019). Umkm Sebagai Pilar Membangun Ekonomi Bangsa MSMES The Pillar For Economy. Jurnal Rep: Riset Ekonomi Pembangunan, 4(2).

Sujian Suretno. (2019). Instrumen Bunga dan Bagi Hasil dalam Dunia Bank. AdDeenar: Jurnal Bank Syariah.

Mohamad Nur Singgih. (2007). Strategi Penguatan Usaha Mikro Kecil Menengah (Umkm) Sebagai Refleksi Pembelajaran Krisis Ekonomi Indonesia, Jurnal Ekonomi Modernisasi, 3(3).

Hendy Herijanto. (2016). Prinsip, Ketentuan, dan Karakteristik Pembiayaan (Bank) Syariah. Jurnal Islaminomic, 5(2).

Nanik Eprianti. (2019). Penerapan Prinsip 5c Terhadap Tingkat Non Performing Financing (NPF). Amwaluna: Jurnal Ekonomi dan Keuangan Syariah, 3(2).

Y. Sri Susilo. (2010). Strategi Bertahan Industri Makanan Skala Kecil Pasca Kenaikan Harga Pangan dan Energi di Kota Yogyakarta. Ekuitas, 14(2).

L Anggraeni, Herdiana P, Salahuddin EA, Ranti W. (2013). Akses UMKM Terhadap Pembiayaan Mikro Syariah dan Dampaknya Terhadap Perkembangan Usaha: Kasus BMT Tadbiirul Ummah, Kabupaten Bogor. Jurnal Al-Muzara'ah, I(1).

\section{Sumber dari Buku}

Abu Bakar Jabir Al-Jazairi. (2015). Tafsir Alquran Al-Aisa. Darus Sunnah Press. 
Ahmad Hasan Ridwan. (2004). BMT \& Bank Islam Intrumen Lembaga Keuangan Syariah. Bandung: Pustaka Bani Quraisy.

Alan Bryman. (2008). Social Research Method, 4th Edition. Oxford: University Press.

Alquran dan Terjemahnya, Departemen Agama Republik Indonesia.

Amalia, Euis. (2009). Keadilan Distributif dalam Ekonomi Islam. Jakarta: Rajawali Press.

Bernd Reiter. (2017). Theory and Methodology of Exploratory Social Science Research. University of South Florida, Scholar Commons.

Hasnil Hasyim. Perilaku Debitur dalam Menentukan Pembiayaan Syariah. AdDeenar: Jurnal Bank Syariah.

Ina Sholati Cahyaningrum. (2017). Pengaruh Sektor Riil dan Keuangan Syariah Terhadap Pertumbuhan Ekonomi di Indonesia Tahun 20072014. An-Nisbah, 04.

Irfadilla (2011). Peran Bank Syariah dalam Mendorong Usaha Kecil dan Menengah Menurut Tinjauan Ekonomi Islam, Universitas Islam Negeri Sultan Syarif Karim

Sage Research Method, What Is Exploration?: In: Exploratory Research in the Social Sciences, SAGE Publications, Inc, January 13, 2019 , DOI: http://dx.doi.org/10.4135/9781412984 $\underline{249}$

Sri Maulida, Ahmad Yunani. (t.t.). Peluang dan Tantangan Pengembangan Usaha Mikro Kecil Menengah (UMKM) dari Berbagai Aspek Ekonomi.
Sujian Suretno. (2018). Jual Beli dalam Perspektif Alquran. Ad-Deenar: Jurnal Bank Syariah.

Sujian Suretno. (2018). Pelaksanaan Musyarakah di Bank Syariah Mandiri, Kajian Prinsip Keadilan dan Kepatuhan Syariah. Cirebon: Nusa Litera Inspirasi.

W. Gulo. (2000). Metodologi Penelitian. Jakarta: Gramedia Widiasarana Indonesia.

Suyitno. (2018). Metode Penelitian Kualitatif, Konsep, Prinsip, dan Operasionalnya. Tulung Agung: Akademia Pustaka.

Sandu Siyoto, Ali Sodik. (2015). Dasar Metodologi Penelitian. Yogyakarta: Literasi Media Publishing.

Tambunan,Tulus. Usaha Mikro Kecil dan Menengah di Indonesia.

\section{Sumber dari Internet}

http://www.deliknews.com/2015/12/29/eko nomi-terpuruk-kado-jokowi- jk-2016untuk-rakyat/, Ekonomi Terpuruk, Kado Jokowi-Jk 2016 untuk Rakyat, diunduh pada hari Jum' at tanggal 23 Desember 2016.

https://katadata.co.id/berita/2018/10/25/staf sus- ekonomi- jokowi- paparkanprogram- kemiskinan- tujuh-erapresiden-ri, Rizka Alika, Stafsus Jokowi Paparkan Program Penurunan Kemiskinan 7 Era Presiden RI, Diakses Pada Tanggal 29 Maret 2020.

https://www.ojk.go.id/id/kanal/syariah/data -dan-statistik/statistik- bank-syariah/ Pages/ Statistik- Bank-Syariah--Agustus-2019.aspx , diakses tanggal 1 Desember 2019.

https://www.kompasiana.com/rizkykarokar o/56307 b13c823bd5811780040/4empat-prinsip-dalam- mengelola- 
perbankan, 4 (empat) Prinsip dalam Mengelola Perbankan, diunduh pada tanggal 30 Maret 2020.

Undang-undang Bank Syariah No.21 Tahun 2008.

Undang-undang Bank Syariah No.7 Tahun 1992. 